-Note-

\title{
Comparison of the Occurrence of Transportation-associated Fever in 2 Years Old Thoroughbreds before and after Introduction of Prophylactic Marbofloxacin Administration
}

\author{
Yoshiro ENDO $^{1 \#}$, Takeru TSUCHIYA ${ }^{1 \#}$, Kentaro AKIYAMA ${ }^{1}$, Naoya TAKEBE ${ }^{1}$, Kenji NAKAI $^{1}$, \\ Kenji KOROSUE ${ }^{1}$, Mutsuki ISHIMARU ${ }^{1}$, Nao TSUZUKI $^{2}$ and Seiji HOBO ${ }^{3 *}$ \\ ${ }^{1}$ Hidaka Training and Research Center, Japan Racing Association, Hokkaido 057-0171, Japan \\ ${ }^{2}$ Laboratory of Veterinary Surgery, Faculty of Agriculture, University of Miyazaki, Miyazaki 880-0036, Japan \\ 3Joint Faculty of Veterinary Medicine, Kagoshima University, Kagoshima 890-0065, Japan
}

In order to reveal the preventive effect of marbofloxacin (MRFX) administration just before transportation, we compared the occurrence of transportation-associated fever before and after introduction of MRFX administration. After the introduction of prophylactic MRFX administration, the rectal temperatures of horses after transportation were significantly lower than before the introduction of MRFX administration $(P<0.01)$ and the number of febrile horses was significantly lower than before the introduction of MRFX administration $(P<0.01)$. In conclusion, these results show that prophylactic MRFX administration just before transportation is clinically effective at preventing transportation-associated fever.

\author{
J. Equine Sci. \\ Vol. 25, No. 4 \\ pp. 79-81, 2014
}

It is known that the risk of fever increases markedly when Thoroughbred racehorses are transported by vehicle over $20 \mathrm{hr}[6,7]$. This is called "transportation-associated fever", it is mainly caused by the infection of the bronchoalveolar regions with Streptococcus equi subsp zooepidemicus that is resident in the tonsillar tissues and trachea of healthy horses $[5,7,9]$. Once transportation-associated fever occurs, multiple administrations of antibiotics (e.g., cephalothin sodium) are required for treatment [8]. In some cases bronchoalveolar lavage or thoracic cavity drainage is also needed [5]. Severe cases can progress to pneumonia and death may result from delay of treatment [7].

Enrofloxacin (ERFX) was reported to have antibacterial activity against Streptococcus equi subsp zooepidemicus [3], and it was also shown that MRFX was effective over $24 \mathrm{hr}[1,2]$. Therefore, we hypothesized that fluoroquinolone antibiotics would protect horses from transportationassociated fever. We divided horses to be transported into

Received: September 29, 2014

Accepted: November 7, 2014

*Corresponding author: e-mail: k2088185@kadai.jp

\#These authors contributed equally to this study.

C2014 Japanese Society of Equine Science

This is an open-access article distributed under the terms of the Creative Commons Attribution Non-Commercial No Derivatives (bync-nd) License $<$ http://creativecommons.org/licenses/by-nc-nd/3.0/ . an administration group and a control group, and compared the properties of blood. The administration group was given ERFX, $5 \mathrm{mg} / \mathrm{kg}$, i.v. or MRFX, $2 \mathrm{mg} / \mathrm{kg}$, i.v., just before transportation [4, 8]. The serum amyloid A (an inflammation marker) of the administration group was significantly lower than that of the control group, suggesting that bacterial infection had been inhibited $[4,8]$. However, the rectal temperature of the two groups were not significantly different [4].

The objective of this study was to verify the clinical effects of MRFX administration by comparison of the occurrence of transportation-associated fever before and after the introduction of prophylactic MRFX administration.

Two-hundred and eleven healthy Thoroughbreds (106 males and 105 females; 2 years old) that were transported from Hidaka Training and Research Center in Hokkaido Prefecture to Hanshin Racecourse in Hyogo Prefecture (distance 1,540 km, transportation time $36 \mathrm{hr}$ ) or Nakayama Racecourse in Chiba Prefecture (distance 1,210 km, transportation time $26 \mathrm{hr}$ ) were investigated in this study (Table 1). In 2008, 2012 and 2013, we selected the same route and arrived at the same time by adjusting the length of journey break times. Fifty horses that were transported in 2007 and 49 horses transported in 2008 did not receive antibiotics before transportation. Fifty-six horses transported in 2012 and 56 horses transported in 2013 were administered MRFX 
Table 1. Horse groups investigated

\begin{tabular}{|c|c|c|c|c|c|c|c|c|}
\hline \multirow{2}{*}{$\begin{array}{c}\text { MRFX } \\
\text { administration }\end{array}$} & \multirow{2}{*}{$\begin{array}{l}\text { Transported } \\
\text { Year }\end{array}$} & \multirow{2}{*}{ Departure } & \multirow{2}{*}{ Arrival } & \multirow{2}{*}{$\begin{array}{l}\text { Distance } \\
(\mathrm{km})\end{array}$} & \multirow{2}{*}{$\begin{array}{l}\text { Transportation Time } \\
\text { (hours) }\end{array}$} & \multicolumn{3}{|c|}{ Horses number } \\
\hline & & & & & & Male & Female & Total \\
\hline- & 2007 & Hokkaido & Hyogo & 1,540 & 36 & 24 & 26 & 50 \\
\hline- & 2008 & Hokkaido & Chiba & 1,210 & 26 & 25 & 24 & 49 \\
\hline+ & 2012 & Hokkaido & Chiba & 1,210 & 26 & 27 & 29 & 56 \\
\hline+ & 2013 & Hokkaido & Chiba & 1,210 & 26 & 30 & 26 & 56 \\
\hline
\end{tabular}

MRFX=marbofloxacin, - : not administered, +: administered.

(Marbocyl 10\%, Meiji, Tokyo, Japan) just before transportation. The dose of MRFX was $2 \mathrm{mg} / \mathrm{kg}$, IV, based on previous studies $[1,2]$.

Rectal temperatures before and after transportation and the number of febrile horses after transportation were compared. At first, rectal temperatures are expressed as mean $\pm \mathrm{SD}$ and were evaluated using the Bartlett test. Because the data was non-homogeneous, it was subjected to a nonparametric test (Kruskal-Wallis), secondly. In tertiary, rectal temperatures were evaluated using a multiple comparison test for non-parametric data (Steel-Dwass). Furthermore, the number of febrile horses was evaluated using the Chi-square for independence test. All analyses were upper -tailed. Values of $P<0.05$ were considered significant. Equine practitioners with more than 5 years clinical experience decided treatments from clinical signs (e.g., rectal temperature, soundness and appetite, etc.). Severe cases with clinical signs of rectal temperature over $39.0^{\circ} \mathrm{C}$, and decreased or unsound appetite were given multiple administrations of cephalothin sodium (Coaxin ${ }^{\circledR}$, Chemix, Yokohama, Japan), an antibiotic that is highly specific to Streptococcus equi subsp zooepidemicus. The dose of cephalothin sodium was $20 \mathrm{mg} / \mathrm{kg}$, IV, every $6 \mathrm{hr}$, based on a previous study [8]. Mild cases with clinical signs of rectal temperature over $38.5^{\circ} \mathrm{C}$ but sound or good appetite were administered a penicillinstreptomycin combination (Mycillin ${ }^{\circledR}$, Meiji, Tokyo, Japan) as a treatment for transportation-associated fever. The dose of Mycillin was penicillin $(8,000 \mathrm{U} / \mathrm{kg})$ and streptomycin $(10 \mathrm{mg} / \mathrm{kg}), \mathrm{IM}$, every $24 \mathrm{hr}$ [8].

There were no differences among the 4 groups in rectal temperature before transportation (Table 2). However, the rectal temperature after transportation was significantly lower (between 2007 and 2013, 2008 and 2012, 2008 and 2013, respectively $P<0.01$ ) after the introduction of prophylactic MRFX administration than before the introduction of MRFX administration. After transportation, there were 19 febrile horses before the introduction of MRFX administration, but there were only 7 febrile horses after its introduction (Table 3). The number of febrile horses after the introduction of prophylactic MRFX administration was significantly lower than before the introduction of MRFX administration $(P<0.01)$. There were 5 severe cases which received cephalothin sodium before the introduction of prophylactic antibiotic administration, but there was only one case after its introduction. Furthermore, there were 14 mild cases which were given a penicillin-streptomycin combination, but there were only 6 horses after the introduction of prophylactic antibiotic administration. There was no horse that presented with colic or shock after being given a dose of MRFX.

We previously reported the high preventive effect of ERFX for transportation-associated fever [8]. EFRX has an antibacterial spectrum covering pathogenic bacteria. However, the ERFX formulation is strongly alkaline and highly tissue invasive. Moreover, the potential for necrosis of tissue from leaking injections is high, because the risk of leakage is increased by the large dose volume required. In contrast, MRFX formulation exhibits little local tissue damage, even when administered by the subcutaneous or intramuscular route $[1,2]$. In the present study, no horse indicated a side-effect after the administration of MRFX, so the high safety of MRFX was confirmed.

In this study, rectal temperatures before and after transportation, and treatments after transportation were compared. Rectal temperatures after transportation after the introduction of prophylactic MRFX administration were significantly lower than those before the introduction of MRFX administration, demonstrating the preventive effect of MRFX for transportation-associated fever. Among the horses given MRFX just before transportation, fewer horses needed post-transportation treatment and those that did need treatment showed milder manifestations of transportationassociated fever. Among the horses before the introduction of MRFX administration, there were 50 horses transported for $36 \mathrm{hr}$ and 49 horses transported for $26 \mathrm{hr}$. However, we treated them as equivalent because a significant difference was not found in rectal temperature after their transportation.

In conclusion, we have demonstrated that the prophylactic MRFX administration just before transportation is clinically effective at preventing transportation-associated fever. 
Table 2. Rectal temperature before and after transportation

\begin{tabular}{ccccc}
\hline \multirow{2}{*}{ MRFX administration } & Transported Year & Horses number & \multicolumn{2}{c}{ Rectal Temperature $\left({ }^{\circ} \mathrm{C}\right)$} \\
\cline { 4 - 5 } & 2007 & 50 & $38.0 \pm 0.22$ & $38.5 \pm 0.40^{\mathrm{a}}$ \\
\hline- & 2008 & 49 & $37.9 \pm 0.16$ & $38.6 \pm 0.42^{\mathrm{b}}$ \\
- & 2012 & 56 & $37.9 \pm 0.18$ & $38.3 \pm 0.26^{\mathrm{b}}$ \\
+ & 2013 & 56 & $37.9 \pm 0.25$ & $38.3 \pm 0.21^{\mathrm{ab}}$ \\
\hline
\end{tabular}

MRFX $=$ marbofloxacin, - : not administered, $+:$ administered, $a, b$ : within the column, values with same superscript letters are significantly $(P<0.01)$ different according to the Steel-Dwass test, data are expressed mean $\pm \mathrm{SD}$.

Table 3. Treatment after transportation

\begin{tabular}{ccccc}
\hline \multirow{2}{*}{ MRFX administration } & \multirow{2}{*}{ Transported Year } & \multirow{2}{*}{ Horses number } & \multicolumn{2}{c}{ Horses number } \\
\cline { 3 - 5 } & & & Not febrile & Febrile \\
\hline- & $2007-2008$ & 112 & 80 & $19\left(14^{\mathrm{A}}, 5^{\mathrm{B}}\right)$ \\
+ & $2012-2013$ & 105 & $7\left(6^{\mathrm{A}}, 1^{\mathrm{B}}\right)$ \\
\hline
\end{tabular}

MRFX=marbofloxacin, A: number of horses administered penicillin-streptomycin combination, B: number of horses administered cephalothin sodium. The number of horses needing treatment was significantly lower $(P<0.01)$ according to the Chi-square for independence test among the horses given MRFX before transportation.

\section{References}

1. Bousquet-Melou, A., Bernard, S., Schneider, M., and Toutain, P.L. 2002. Pharmacokinetics of marbofloxacin in horses. Equine Vet. J. 34: 366-372. [Medline] [CrossRef]

2. Carretero, M., Rodríguez, C., San Andrés, M.I., Forés, P., de Lucas, J.J., Nieto, J., Waxman, S., San Andrés, M.D., and González, F. 2002. Pharmacokinetics of marbofloxacin in mature horses after single intravenous and intramuscular administration. Equine Vet. J. 34: 360-365. [Medline] [CrossRef]

3. Davis, E., Rush, B.R., Herr, L.G., and Ewert, K.M. 2006. Enrofloxacin use in a long-distance transport model of equine respiratory disease. Vet. Ther. 7: 232-242. [Medline]

4. Endo, Y., Tsuchiya, T., Omura, T., Nakai, K., Korosue, K., Ishimaru, M., Ishikawa, Y., and Hobo, S. 2014. Effects of pre-shipping marbofloxacin administration on fever and blood properties in healthy Thoroughbreds transported a long distance. J. Vet. Med. Sci. (in press). [Medline] [CrossRef]

5. Ito, S., Hobo, S., Eto, D., and Sato, H. 2001. Bronchoalve- olar lavage for the diagnosis and treatment of pneumonia associated with transport in Thoroughbred racehorses. $J$. Vet. Med. Sci. 63: 1263-1269. [Medline] [CrossRef]

6. Oikawa, M., and Kusunose, R. 1995. Some epidemiologocal aspects of equine respiratory disease associated with transport. J. Equine Sci. 6: 25-29. [CrossRef]

7. Oikawa, M., Takagi, S., Anzai, R., Yoshikawa, H., and Yoshikawa, T. 1995. Pathology of equine respiratory disease occurring in association with transport. J. Comp. Pathol. 113: 29-43. [Medline] [CrossRef]

8. Tsuchiya, T., Hobo, S., Endo, Y., Narita, S., and Sakamoto, K. 2012. Effects of a single dose of enrofloxacin on body temperature and tracheobronchial neutrophil count in healthy Thoroughbreds premedicated with interferon- $\alpha$ and undergoing long-distance transportation. Am. J. Vet. Res. 73: 968-972. [Medline] [CrossRef]

9. Yoshikawa, H., Yasu, T., Ueki, H., Oyamada, T., Oishi, H., Anzai, T., Oikawa, M., and Yoshikawa, T. 2003. Pneumonia in horses induced by intrapulmonary inoculation of Streptococcus equi subsp. zooepidemicus. J. Vet. Med. Sci. 65: 787-792. [Medline] [CrossRef] 